R OCZNIKI NAUK PRA WNYCH

Tom XXXI, numer 3 - 2021, s. 127-149

DOI: http://doi.org/10.18290/rnp21313.8

\title{
WIOLETA WASIL-RUSECKA
}

Uniwersytet Kardynała Stefana Wyszyńskiego

w.wasil-rusecka@uksw.edu.pl

ORCID: https://orcid.org/0000-0002-6286-1055

\section{ROLA DIALOGU SPOŁECZNEGO W ROZWIAQZYWANIU KONFLIKTÓW SPOŁECZNYCH}

\author{
THE ROLE OF SOCIAL DIALOGUE IN SOLVING SOCIAL CONFLICTS
}

\begin{abstract}
The principle of social dialogue included in the preamble to the Constitution of the Republic of Poland laid at the basis of relations in the state. The analysis of how social dialogue impacts interpersonal relations leads to reflection on the role it plays in solving social conflicts. The article presents the results of research carried out in order to find an answer to the question about the importance of social dialogue in resolving disputes and relieving social tensions. Therefore, the study presents the forms that dialogue takes when trying to achieve its goal, which is to maintain social peace.

When presenting the results of the research, it is necessary to signal a disturbing phenomenon of trivialising the role of the institutions of social dialogue. The marginalisation of said dialogue, being one of the guarantors of a democratic state ruled by law, paves the way for autocracy. Recognizing the key role of social dialogue in resolving conflicts, it seems justified to call for the most frequent use of those forms of dispute resolution that are characteristic of said dialogue. The article encourages active participation in the dialogue, and also reminds of the obligation of state authorities to conduct it.
\end{abstract}

Keywords: social dialogue; social conflict; the Constitution of the Republic of Poland; social peace; autocracy

\section{WPROWADZENIE}

Obowiązująca w Polsce koncepcja „dialogu społecznego” została określona w Konstytucji $\mathrm{RP}^{1}$. Ustawodawca odwołuje się do idei dialogu społecznego

\footnotetext{
${ }^{1}$ Ustawa z dnia 2 kwietnia 1997 r. - Konstytucja Rzeczypospolitej Polskiej, Dz.U. z 1997 r., $\mathrm{Nr} 78$, poz. 483 ze zm.
} 
w dwóch miejscach. Wspomina o niej we wstępie do ustawy zasadniczej, wskazując, że „prawa podstawowe dla państwa oparte są na [...] dialogu społecznym”, oraz w art. 20 opierając m.in. na „dialogu i współpracy partnerów społecznych" społeczną gospodarkę rynkową, stanowiącą podstawy ustroju gospodarczego państwa. Dialog społeczny, do którego odniesiono się w preambule, został włączony w poczet zasad podstawowych obok „wolności i sprawiedliwości, współdziałaniu władz [...] zasadzie pomocniczości”, na których oparto Konstytucję RP. Zasady te przenikają treść ustawy zasadniczej, stając się wytycznymi do tworzenia unormowań, za pomocą których zostaną zrealizowane ${ }^{2}$. I tak $\mathrm{w}$ przypadku zasady dialogu społecznego znajduje ona rozwinięcie w przepisach Konstytucji RP, w których gwarantuje m.in.: wolność środków społecznego przekazu (art. 14), wolność wyrażania poglądów (art. 54), wolność zrzeszania się (art. 11 i 13), prawo petycji (art. 63) czy prawo udziału w referendum (art. 62). Idea dialogu społecznego legła u podstaw nowego modelu państwa polskiego po 1989 r., zgodnie z którą decyzje polityczne zapadają poprzez negocjacje, dążąc dzięki temu do zachowania ładu społecznego ${ }^{3}$. Dążenie to jako główny cel dialogu społecznego przesądza o jego funkcji w rozwiązywaniu konfliktów w państwie. Dialog ten bowiem przyczynia się do łagodzenia napięć i sprzecznych interesów, które występują między różnymi grupami społecznymi ${ }^{4}$.

W artykule zostanie zaprezentowana rola dialogu społecznego, jaką odgrywa $\mathrm{w}$ rozwiązywaniu konfliktów społecznych. Ponadto, omówione zostanie znaczenie dialogu społecznego oraz formy, jakie przyjmuje, aby osiągnąć cel, do którego został powołany, tj. dążenie do zachowania pokoju społecznego ${ }^{5}$.

\section{Definicja DiAlogu SPOŁECZNEGO}

Pojęcie „dialog społeczny” jest terminem wieloznacznym. Słowo „dialog” wywodzi się z języka greckiego, jako diálogos - rozmowa, która może oznaczać wymianę zdań oraz poglądów dwóch lub więcej podmiotów. Termin ten

\footnotetext{
${ }^{2}$ Por. L. Garlicki, Wstęp, [w:] Konstytucja Rzeczypospolitej Polskiej. Komentarz, red. L. Garlicki, t. V, Warszawa: Wydawnictwo Sejmowe 2007, s. 15.

${ }^{3}$ Por. T. Zieliński, Nowy ład pracy - rzeczywistość $i$ wizja przyszłości, [w:] Nowy lad pracy w Polsce i w Europie, red. M. Matey, Warszawa: Wydawnictwo Naukowe Scholar 1997, s. 40.

${ }^{4}$ Por. J. GardawsKi, Dialog społeczny od praw cechowych do dyrektyw unijnych, „Dialog. Pismo Dialogu Społecznego" 2006, nr 1, s. 11.

${ }^{5}$ A. OGONOwsKi, Ewolucja instytucji dialogu społecznego w Polsce po 1989 roku, Warszawa: Wydawnictwo Sejmowe 2018, s. 7.
} 
można także rozumieć jako sposób mówienia, z greckiego dialektikē bądź diálektos $^{6}$. Stownik języka polskiego definiuje pojęcie dialogu jako „szereg rozmów, negocjacji i innych działań mających doprowadzić do porozumienia między stronami konfliktu"7.

Drugi człon pojęcia „dialog społeczny” jest wyrazem pokrewnym wobec terminu „społeczeństwo”, który według Stownika języka polskiego oznacza „ogół ludzi pozostających we wzajemnych stosunkach wynikających z warunków życia, podziału pracy i udziału w życiu kulturalnym; też: ogół obywateli danego okręgu, miasta itp.”. Samo zaś określenie „społeczny” oznacza m.in. „zorganizowany przez jakąś społeczność samodzielnie, bez udziału państwa" ". Wracając do rozumienia słowa „społeczeństwo”, podkreślić należy, że terminem tym opisuje się dużą zbiorowość, która zamieszkuje określony teren, odróżnia się od innych wspólną kulturą, tożsamością oraz siecią wspólnych stosunków społecznych. Sformułowanie to jest czasem używane w celu opisania całej ludzkości. Połączenie dwóch słów „dialog” i „społeczny" oznacza, że prowadzony dialog nie skupia się tylko na interesach jednostkowych, a obejmuje całe społeczeństwo, a więc nastawiony jest na interesy wspólne?.

Rudymentarne znaczenie dialogu ma wyraźne konotacje językowe. Pojęcie dialogu w wąskim rozumieniu jest bliskie terminowi rozmowy i dyskusji ${ }^{10}$. A. Ogonowski opierając się na lingwistycznym znaczeniu kategorii „dialogu społecznego" stwierdza, że jest to „forma debaty przynajmniej dwóch podmiotów (reprezentujących interesy określonej społeczności) o przeciwstawnych stanowiskach, które zmierzają do znalezienia kompromisu w określonej sprawie, co w konsekwencji umożliwi im podjęcie wspólnego działania" ${ }^{11}$.

Dialog można traktować jako budulec światowego dorobku cywilizacyjnego, bowiem w historii najbardziej płodne osiągnięcia pojawiały się zazwyczaj tam, gdzie następowała konfrontacja różnych sposobów ujmowania zagadnień.

\footnotetext{
${ }^{6}$ Por. tamże, s. 45

${ }^{7}$ Stownik języka polskiego powstał na podstawie Słownika 100 tysięcy potrzebnych słów, red. J. Bralczyk, wyd. I, Warszawa 2005. Autorem aktualizacji wersji on-line jest Lidia DRABIK, hasło: Dialog, https://sjp.pwn.pl/sjp/;2555065 [dostęp: 14.02.2021].

${ }^{8}$ Tamże, hasło: Społeczny, https://sjp.pwn.pl/sjp/spoleczny;2523113.html [dostęp: 14.02.2021].

${ }^{9}$ Por. A. ANACIK, S. KRUPNIK, A. OTRĘBA [i in.], Diagnoza stanu rozwoju sektorowego dialogu społecznego w skali ogólnopolskiej - badania ilościowe, Kraków: Wyższa Szkoła Europejska 2007, s. 26

${ }^{10}$ Por. A. Rossmanith, Dialogiczna koncepcja prawa, Warszawa: Wolters Kluwer 2019, s. 76-75.

${ }^{11}$ A. OGONOwSKI, Ewolucja instytucji dialogu społecznego, s. 19.
} 
W kulturze europejskiej w kwestii prowadzenia dialogu żywa jest tradycja judeochrześcijańska, Jan Paweł II stwierdził: „Cała Ewangelia jest dialogiem z człowiekiem, z pokoleniami, z narodami, z tradycjami, ale jest ona zawsze i nieustannie dialogiem z człowiekiem, jednym, jedynym i niepowtarzalnym" ${ }^{12}$. Papież ten w szczególny sposób zwracał uwagę na konieczność kultury dialogu, nie tylko międzyreligijnego czy międzykulturowego. W humanistycznym przesłaniu I. Kanta synonimami dialogu są kultura pokoju czy kultura kooperacji. Dla niektórych zaś, jak dla wybitnego niemieckiego filozofa J. Habermasa, twórcy m.in. „etyki dyskusji”, dialog był wręcz synonimem demokracji ${ }^{13}$. Przyjmuje się, że w ramach tego rozumienia uwypukla się sposób postrzegania dialogu jako metody poszukiwania porozumienia między różnymi stanowiskami. Konfrontacja różnych, choć jednakowo ważnych stanowisk pozwala na przerodzenie dialogu w dyskurs, stając się tym samym czymś więcej niż tylko rozmową ${ }^{14}$.

W naukach społecznych „dialog społeczny” traktowany jest jako instytucja realizująca postulaty idei demokracji partycypacyjnej ${ }^{15}$. W rozumowaniu tym dialog stanowi forum dla reprezentacji i negocjacji interesów między poszczególnymi jego uczestnikami. W tej gałęzi nauki można spotkać się ze znaczeniem dialogu społecznego jako mniej lub bardziej zinstytucjonalizowanego sposobu komunikowania się między władzą państwową a różnymi podmiotami społecznymi reprezentującymi interesy znaczących odłamów społeczeństwa, których zasadniczą funkcją jest przekazywanie ustaleń dotyczących celów, instrumentów i strategii wdrażania jakiegoś rodzaju polityki publicznej. Dialog społeczny traktowany jest także jako sposób umacniania polityki państwa i omijania ułomności mechanizmów demokracji parlamentarnej ${ }^{16}$.

Polskie ustawodawstwo nie definiuje pojęcia dialogu społecznego, a jedynie powołuje się na nie. Do procesu dialogu społecznego odwołano się w Konstytucji RP, w ustawie z dnia 24 lipca 2015 r. o Radzie Dialogu Społecznego i innych instytucjach dialogu społecznego (tekst jedn.: Dz.U. z 2018 r., poz. 2232 ze zm. ${ }^{17}$ ), ustawie z dnia 7 kwietnia 2006 r. o informowaniu pracowników i przeprowadzaniu z nimi konsultacji (Dz.U. z 2006 r.,

\footnotetext{
12 Jan PAWE⿺ II, Nauczanie społeczne, t. III, Warszawa: Ośrodek Dokumentacji i Studiów Społecznych 1984, s. 438-439.

${ }^{13}$ Zob. H. IzDEBSKI, Fundamenty współczesnych państw, Warszawa: LexisNexis 2007, s. 52.

${ }^{14}$ Por. A. Rossmanith, Dialogiczna koncepcja prawa, s. 75.

${ }^{15}$ Zob. B. GĄCIARZ, W. PAŃKów, Dialog społeczny po polsku - fikcja czy szansa?, Warszawa: Instytut Spraw Publicznych 2001, s. 13-14.

${ }^{16}$ Por. tamże, s. 17.

${ }^{17}$ Dalej: ustawa o dialogu społecznym.
} 
$\mathrm{Nr} 79$, poz. 550) oraz w ustawie z dnia 20 kwietnia 2004 r. o promocji zatrudnienia i instytucjach rynku pracy (tekst jedn.: Dz.U. z 2020 r., poz. 1409). Istotne elementy doktrynalne dotyczące dialogu społecznego, w tym znaczenie podstawowych pojęć związanych z dialogiem, odnaleźć można w dokumencie programowym rządu „Zasady dialogu społecznego”, przyjętym przez Radę Ministrów 22 października 2002 r., oraz w załączniku nr 1 do tego dokumentu: „Dialog społeczny - istota, pojęcia, metody”18. W dokumencie tym wyróżniono trzy rodzaje dialogu, określając je w zależności od podmiotów biorących w nim udział, jako: dialog tradycyjny, $\mathrm{z}$ udziałem partnerów społecznych, dialog obywatelski oraz dialog z udziałem przedstawicielstw samorządów: zawodowych, gospodarczych i terytorialnych. Należy jednak zaznaczyć, że dokument ten nie tylko miał, ale i wciąż ma o wiele większy walor doktrynalny aniżeli walor praktyczny.

Jak wskazano na wstępie niniejszych rozważań, ustawa zasadnicza formułuje określoną koncepcję dialogu społecznego, nawiązując do idei dialogu w preambule do Konstytucji RP oraz w art. 20, który określa podstawy ustroju gospodarczego Rzeczypospolitej Polskiej. Odnosząc się do dialogu społecznego posługuje się dwoma terminami - „dialog społeczny” oraz „dialog partnerów społecznych". Kluczowe dla interpretacji użytych przez Ustawodawcę pojęć pozostaje ustalenie uczestników dialogu przewidzianego w ustawie zasadniczej.

S. Stadniczeńko ${ }^{19}$ uważa, że pojęcie dialogu użyte w preambule jest szersze, aniżeli pojęcie to zastosowane w art. 20 Konstytucji RP. Autor ten przyjmuje, że „dialog społeczny” ze wstępu do ustawy zasadniczej posiada nieograniczony zakres podmiotowy i może przyjmować różne formy. A. Ogonowski rozważa, czy ustawodawca konstytucyjny wspominając w preambule o dialogu społecznym miał na myśli dialog władzy ze społeczeństwem, czy może dialog pomiędzy reprezentantami różnych grup interesów ${ }^{20}$. Rozstrzygając tę wątpliwość, odwołał się do treści art. 20 Konstytucji RP. Przepis ten wspomina o „dialogu i współpracy partnerów społecznych”. Natomiast w art. 59 ust. 2 ustawy zasadniczej wskazuje się, że partnerzy społeczni „mają prawo do rokowań, w szczególności w celu rozwiązywania sporów zbiorowych, oraz do zawierania układów zbiorowych pracy i innych porozumień". Autor ten przyjmuje, że Ustawodawca dla oznaczenia dialogu społecznego

\footnotetext{
${ }^{18}$ Dalej: załącznik nr 1.

${ }^{19}$ Zob. S.L. STADNICZEŃKO, Konstytucjonalizacja dialogu spotecznego, „Studia Iuridica Lublinensia" 2014, t. 22, s. 329.

${ }^{20}$ Por. A. OGONOWSKi, Ewolucja instytucji dialogu społecznego, s. 10.
} 
pomiędzy reprezentantami różnych grup interesów funkcjonujących w państwie stosuje pojęcie „dialogu i współpracy partnerów społecznych” z art. 20 Konstytucji $\mathrm{RP}^{21}$. Dialog społeczny umiejscowiony w preambule stanowi zaś odwołanie do opartych na stałym dialogu stosunków pomiędzy władzami publicznymi i społeczeństwem m.in. w sferze podejmowania rozstrzygnięć dotyczących spraw publicznych ${ }^{22}$.

W Konstytucji RP przyjęto dwojakie znaczenie dialogu społecznego. Szerokie, którego podstawę prawną stanowi preambuła, oraz wąskie - odwołujące się do formuły „dialogu i współpracy partnerów społecznych” z art. 20. Skupiając uwagę na pierwszym z wymienionych znaczeń, podkreślić należy, że jest on związany z postępującym rozwojem społeczeństw postindustrialnych i zmian w strukturze społecznej. Tradycyjna (wąska) formuła dialogu społecznego przestała być wystarczająca do rozwiązania powstających problemów społecznych. Konieczne stało się zatem rozszerzenie praktyki dialogu na struktury tzw. trzeciego sektora, pod pojęciem którym należy rozumieć zrzeszenia obywateli i instytucji samorządu terytorialnego, zawodowego, gospodarczego $^{23}$. Z uwagi na obecność silnego pierwiastka społecznego w rozumianym szeroko dialogu społecznym, od kilku lat, a szczególnie po akcesji Polski do Unii Europejskiej zaczął on być nazywany „dialogiem obywatelskim" ${ }^{24}$. Określeniem tym w dalszej części opracowania będzie się posługiwać także autor niniejszych rozważań, oznaczając dialog społeczny w szerszym rozumieniu. Zaznaczając jednocześnie, że „problematyka dialogu obywatelskiego z zastosowaniem ujęć definicyjnych jest bardzo słabo rozpoznana zarówno $\mathrm{w}$ ramach regulacji prawnych, jak i w literaturze naukowej i publicystycznej" 25 . Jest to pojęcie nowe, w literaturze nie bez kozery nazywane „młodszym bratem dialogu społecznego” 26 .

Zgodnie z zaproponowaną przez Radę Ministrów definicją dialogu obywatelskiego, określoną w załączniku nr 1, należy rozumieć go jako

sposób komunikowania się między władzą państwową a różnymi partnerami społecznymi, przejawiający się we wzajemnym przekazywaniu sobie opinii, informacji czy ustaleń

${ }^{21}$ Por. tamże.

22 Por. tamże.

${ }^{23}$ Por. B. GĄCIARZ, W. PAŃKów, Dialog społeczny po polsku, s. 17.

${ }^{24}$ Zob. R. Towalski, Dialog społeczny - próba definicji, [w:] Dialog społeczny. Najnowsze dyskusje i koncepcje, red. R. Towalski, Warszawa: Centrum Partnerstwa Społecznego „Dialog” 2007, s. 16.

${ }^{25}$ W. MiszTal, Dialog, to znaczy co?, „Dialog. Pismo Dialogu Społecznego” 2017, nr 1 (52), s. 22.

${ }^{26}$ M. Cisek-Lachowicz, K. Kichewko, Dialog obywatelski $w$ praktyce, „Studia z Polityki Publicznej” 5 (2018), nr 2 (18), s. 61. 
dotyczących celów, instrumentów i strategii wdrażania polityki publicznej. Istotą dialogu obywatelskiego jest stanowienie forum dla reprezentacji interesów między poszczególnymi jego uczestnikami, w tym między partnerami społecznymi (organizacje pozarządowe, społeczne) a odpowiednimi organami władzy publicznej ${ }^{27}$.

Jak przyjmuje się w komentowanym dokumencie, dialog obywatelski może obejmować różnorodne formy komunikowania się władz publicznych $\mathrm{z}$ obywatelami, zorganizowanymi w - najogólniej ujmując - grupy społeczne, które działają na każdej płaszczyźnie życia (m.in. społecznej, ekonomicznej, zawodowej, terytorialnej, światopoglądowej). W odróżnieniu od dialogu tradycyjnego w węższym ujęciu, który dotyczy wyłącznie miejsca pracy, dialog obywatelski odnosi się do „całokształtu miejsca grup obywateli w państwie i społeczeństwie"28.

W doktrynie dialog obywatelski definiowany jest

\begin{abstract}
jako jedna z podstawowych form dyskursu publicznego [...], pozwala zaangażowanym obywatelom [...] na wzięcie udziału w debacie publicznej i wyrażenie poglądów dotyczących (w ich przekonaniu) istotnych problemów. [...] Dialog obywatelski jest formą partycypacji obywatelskiej, która stanowi fundament rozwoju społeczeństwa obywatelskiego oraz wspierania zmian ustrojowych. Jest narzędziem umacniania roli organizacji pozarządowych i samej idei demokracji partycypacyjnej ${ }^{29}$.
\end{abstract}

Jak wynika z powyższego, dialog obywatelski stanowi przestrzeń do wyrażania stanowisk opinii publicznej, celem wywarcia wpływu na decyzje podejmowane przez rządzących $\mathrm{w}$ stosunku do obywateli. Wpisując się tym samym w ideę demokracji uczestniczącej ${ }^{30}$.

W węższym, tradycyjnym ujęciu „dialog społeczny” określany jest jako

całokształt wzajemnych relacji pomiędzy związkami zawodowymi i organizacjami pracodawców. Obejmuje także ich stosunki (dwustronne lub trójstronne) z organami państwowymi, jak rząd i jego agendy, samorząd lokalny czy inne instytucje państwowe. Wyraża się on w mechanizmach rokowań, układów i porozumień oraz rozwiązywaniu sporów zbiorowych, a także komunikacji (wymiany informacji). Dialog społeczny definiowany jest także jako proces stałej interakcji pomiędzy uczestnikami dialogu w celu osiągnięcia porozumienia $\mathrm{w}$ sprawach kontroli nad określonymi zmiennymi społeczno-ekonomicznymi w skali makro i mikro ${ }^{31}$.

${ }^{27}$ Załącznik nr 1 „Dialog społeczny - istota, pojęcia, metody”, s. 16.

${ }^{28}$ Tamże.

${ }^{29}$ W. MiszTal, Dialog, to znaczy co?, s. 27.

${ }^{30}$ Zob. H. IzDEBSKI, Doktryny polityczno-prawne. Fundamenty współczesnych państw, Warszawa: Wolters Kluwer 2017, s. 19.

${ }^{31}$ Załącznik nr 1 „Dialog społeczny - istota, pojęcia, metody”, s. 10. 
Dialog społeczny, jak wynika z cytowanej definicji, zawiera węższy katalog podmiotów aniżeli dialog obywatelski, na tym polega zasadnicza różnica między tymi dwoma rodzajami dialogu. Pomimo że dialog społeczny jest trwale osadzony zarówno koncepcyjnie, jak i legislacyjnie oraz instytucjonalnie w ustroju polskim, to trudno o jego jedną powszechnie akceptowaną definicję.

Międzynarodowa Organizacja Pracy definiuje dialog społeczny jako wszelkiego rodzaju negocjacje, konsultacje lub zwykłą wymianę informacji pomiędzy przedstawicielami rządu, prawodawcami i pracownikami w sprawach będących przedmiotem ich wspólnego zainteresowania, a odnoszących się do polityki społecznej i gospodarczej ${ }^{32}$.

Z powyższych definicji wynika, że dialog społeczny to forma komunikowania się między partnerami społecznymi a przedstawicielami władzy, ale nie we wszystkich sprawach będących przedmiotem zainteresowania stron, a tych które dotykają kwestii społecznych i gospodarczych, a przede wszystkich tych związanych $\mathrm{z}$ miejscem pracy. P. Winczorek rozbudowuje to rozumienie, uwypuklając rozjemczą funkcję dialogu społecznego. Twierdzi on, że dialog społeczny w wąskim rozumieniu oznacza taki sposób ułożenia stosunków między pracodawcami, pracobiorcami i organami władzy publicznej, w którym spory i konflikty (np. płacowe, dotyczące warunków pracy, świadczeń społecznych itp.) rozwiązywane są nie poprzez strajki pracownicze lub lokauty, lecz w drodze rozmów, kompromisów, układów i porozumień $^{33}$. Pokojowemu załatwieniu spraw spornych służy istnienie instytucji prawnych (tj. układy zbiorowe pracy) i swobód obywatelskich, w szczególności wolność tworzenia i przynależności do związków zawodowych oraz stowarzyszeń pracodawców ${ }^{34}$.

Podstawową instytucją, w ramach której może toczyć się dialog ,partnerów społecznych" jest Rada Dialogu Społecznego (dalej: Rada) (wcześniej Komisje Trójstronne). W pracach Rady (wcześniej Komisji) uczestniczą przedstawiciele związków zawodowych, stowarzyszeń pracodawców oraz rządu. W Radzie mogą zapadać decyzje dotyczące warunków pracy i płacy oraz zasad zabezpieczenia społecznego. Nie jest to jednak instytucja konstytucyjna, choć nadanie jej takiego charakteru było postulatem ujętym w „obywatelskim”

${ }^{32}$ Por. International Labour Organization, ILO (2018). Social Dialogue, What is Social Dialogue?, http://www.ilo.org/ifpdial/areas-of-work/social-dialogue/lang--en/index.htm [dostęp: 1.07.2021].

${ }^{33}$ Por. J. Majchrowski, P. Winczorek, Ustrój konstytucyjny Rzeczpospolitej Polskiej, Warszawa: Hortpress Sp. z o.o. 1998, s. 39-40.

${ }^{34}$ Por. tamże, s. 40. 
projekcie Konstytucji ${ }^{35}$. Aktualnie podstawą funkcjonowania Rady (podobnie jak i Komisji Trójstronnej ${ }^{36}$ ) jest ustawa.

W przywoływanych dokumentach Rady Ministrów przewidziano jeszcze jeden rodzaj dialogu. Mowa o pojęciu dialogu z udziałem przedstawicielstw samorządów, który „należy rozumieć jako całokształt wzajemnych stosunków, współdziałania (wymiany informacji, konsultacji, negocjacji) między stronami tego dialogu, tj. pomiędzy poszczególnymi korporacjami (samorządy zawodowe, gospodarcze, terytorialne) a odpowiednimi organami władzy publicznej, w tym administracji rządowej" ${ }^{37}$. Analizując dialog z udziałem przedstawicielstw samorządów, należy zwrócić uwagę na jego specyfikę. Obie strony dialogu wykonują określone władztwo publiczne, przy czym samorządy odpowiedzialne są za tę część władztwa, która została mu powierzona przez drugą stronę tego rodzaju dialogu, tj. państwo.

Przedmiotem takiego dialogu jest wspólne kształtowanie stosunków pomiędzy przedstawicielstwami samorządów a stroną rządową. Koncentruje się on głównie na sposobach wykonywania zadań publicznych, powierzonych samorządom biorącym udział $\mathrm{w}$ dialogu oraz ich finansowania. W przywoływanym dokumencie Rady Ministrów wskazuje się, że: „Powinien on sprzyjać ze swej istoty harmonizowaniu stosunków ekonomicznych i społecznych, łagodzeniu dysproporcji, napięć czy różnego rodzaju konfliktów występujących także na linii władza publiczna - samorządy prawa publicznego"38. Oczekuje się bowiem, że dialog ten pozwoli zapobiec konfliktom. Pomoże uniknąć strat ekonomicznych i zakłóceń występujących w funkcjonowaniu gospodarki.

\section{POJĘCIE KONFLIKTU}

Słowo „konflikt” pochodzi z języka łacińskiego, conflictus - zderzenie. W znaczeniu encyklopedycznym „konflikt” oznacza 1. „przedłużającą się niezgodę między stronami”, 2. „działania zbrojne będące wynikiem takiej niezgody” czy 3. „różnice między wartościami, postawami itp., której nie

\footnotetext{
${ }^{35}$ Zob. http://www.solidarnosc.org.pl/bbial/wp-content/uploads/2017/08/Konstytucja-RP-projekt obywatelski.pdf [dostęp: 12.10.2020].

${ }^{36}$ Ustawa z dnia 6 lipca 2001 r. o Trójstronnej Komisji do Spraw Społeczno-Gospodarczych i wojewódzkich komisjach dialogu społecznego, Dz.U. z 2001 r., Nr 100, poz. 1080 ze zm.

${ }^{37}$ Załącznik nr 1 „Dialog społeczny - istota, pojęcia, metody”, s. 20.

${ }^{38}$ Tamże, s. 24.
} 
sposób usunąć”39. W literaturze przedmiotu konflikt, co do zasady, definiowany jest jako ,występowanie sprzecznych lub konkurencyjnych interesów" ${ }^{40}$. Należy jednak przyjąć, że niezgodność interesów nie wyczerpuje pojęcia konfliktu, który może być konsekwencją różnic co do przekonań, emocji, pełnionych ról, intencji itd. Podkreślić należy, że konflikt jest nieodłącznym elementem relacji międzyludzkich. Można pokusić się o stwierdzenie, że jest zjawiskiem normalnym, naturalnym, wszechobecnym, a czasem użytecznym. A. Żuk przekonuje, że konflikt można traktować jako walkę, która stoi w opozycji do świata pokoju ${ }^{41}$. Zjawisko konfliktu dotyczy każdej sfery życia społecznego, dlatego uzasadnione jest twierdzenie, że są one wszechobecne.

W każdym społeczeństwie funkcjonują grupy społeczne różniące się oczekiwaniami, dążeniami, interesami, poglądami, motywami i in. Grupy te chcą realizować swoje oczekiwania, z uwagi jednak na powstające między nimi różnice dochodzi do konfliktów społecznych ${ }^{42}$. Określenie „społeczny” wskazuje na konflikt, w którym uczestniczą różnego rodzaju grupy interesu. Konflikt ten pozbawiony jest charakteru indywidulanego. W literaturze przedmiotu wskazuje się, że „konflikt społeczny jest naturalnym zjawiskiem w demokracji, której siła polega na dyskusji i wypracowaniu wspólnego stanowiska"43. Należy jednak zaznaczyć, że niekontrolowane nasilenie konfliktu, który jest stałym elementem demokratycznego państwa prawa, może stanowić zagrożenie ładu społecznego.

Przyczynami tego rodzaju konfliktu są najczęściej dysproporcje rozwojowe czy po prostu zróżnicowanie hierarchii wartości w poszczególnych grupach. Na oficjalnej stronie internetowej poświęconej dialogowi społecznemu wskazuje się, że współcześnie najistotniejsze konflikty społeczne, jakie mają miejsce w krajach wysoko rozwiniętych, występują w przemysłowych zakładach pracy ,ze względu na doniosłą rolę przemysłu w życiu społeczno-gospodarczym tych społeczeństw" ${ }^{\prime 4}$.

${ }^{39}$ L. DRABIK, hasło: Konflikt, [w:] Słownik języka polskiego, https://sjp.pwn.pl/sjp/konflikt; 2564275.html [dostęp: 14.02.2020].

${ }^{40}$ J. KozIELECKI, Konflikty, teoria gier i psychologia, Warszawa: Państwowe Wydawnictwo Naukowe 1970, s. 35.

${ }^{41}$ Por. A. ŻuK, Filozofia walki, Lublin: Wydawnictwo UMCS 1996, s. 157.

${ }^{42}$ Por. M. SuchaneK, Mediacja jako metoda rozwiązywania konfliktów spolecznych, „Studia Administracyjne" 2018, nr 10, s. 129.

${ }^{43}$ Tamże.

${ }^{44}$ Por. K. KurzyńSKA, Podstawowe pojęcia. Dialog społeczny, czym jest, hasło: Konflikt społeczny, http://www.dialog.gov.pl/czym-jest-dialog-spoleczny/podstawowe-pojecia/ [dostęp: 14.07.2021]. 
Konflikty społeczne występujące $\mathrm{w}$ ww. miejscach przejawiają się w postaciach zarówno widocznych (np. strajki), jak i ukrytych (tj. bierny upór przejawiający się w lekceważeniu i bojkocie poleceń służbowych, niedbałego wykonywania obowiązków pracowniczych). Przyczynami takiego konfliktu są co do zasady warunki pracy i płacy, ale także i inne bodźce ekonomiczne i pozaekonomiczne ${ }^{45}$. Szczególnym rodzajem konfliktu społecznego związanego z zakładem pracy jest spór zbiorowy.

Zgodnie z art. 1 ustawy z dnia 23 maja 1991 r. o rozwiązywaniu sporów zbiorowych (tekst jedn.: Dz.U. z 2020 r., poz. $123^{46}$ ): „Spór zbiorowy pracowników z pracodawcą lub pracodawcami może dotyczyć warunków pracy, płac lub świadczeń socjalnych oraz praw i wolności związkowych pracowników lub innych grup, którym przysługuje prawo zrzeszania się w związkach zawodowych". Przy tym prawa i interesy zbiorowe pracowników w sporach zbiorowych są reprezentowane przez związki zawodowe, a prawa i interesy pracodawców mogą być reprezentowane przez właściwe organizacje pracodawców. Należy zaznaczyć, że nie jest dopuszczalne prowadzenie sporu zbiorowego w celu poparcia indywidualnych żądań pracowniczych, jeżeli możliwe jest ich rozstrzygnięcie w postępowaniu przed organem rozstrzygającym spory o roszczenia pracowników.

Sposoby rozwiązywania sporów zbiorowych określa przywoływana powyżej ustawa. Są to rokowania, mediacja oraz arbitraż społeczny. Z uwagi na opisowy charakter tej części opracowania nie wydaje się celowe przywoływanie praktycznych przykładów prowadzenia sporów zbiorowych.

Ponadto warto zwrócić uwagę, że w naukach prawnych doktryna na określenie konfliktu zdecydowanie częściej posiłkuje się pojęciem „spór”. Oznacza on ,sytuację, w której jedna ze stron występuje z twierdzeniem, żądaniem, roszczeniem, czy skargą kwestionowaną przez drugą stronę" ${ }^{47}$. Jak przekonuje A. Jakubiak-Mirończuk, pojęcia te są tożsame, a literatura prawnicza oba pojęcia stosuje zamiennie na określenie sytuacji, w której strony podejmują działanie $\mathrm{w}$ celu realizacji sprzecznych interesów ${ }^{48}$. O ile w ujęciu prawnym pojęcia konfliktu i sporu traktowane są niemal równorzędnie, o tyle w ujęciu pozaprawnym spór powstaje na skutek eskalacji i zakomuni-

${ }^{45}$ Por. tamże.

${ }^{46}$ Dalej: ustawa o sporach zbiorowych.

${ }^{47}$ A. JAKUBiak-MirońCZUK, Negocjacje dla prawników. Prawo cywilne, Warszawa: Wolters Kluwer Polska 2010, s. 27, za: L. MorAwski, Proces sądowy a instytucje alternatywne (na przyktadzie sporów cywilnych), „Państwo i Prawo” 1993, z. 1, s. 12; J. KuRCZEwski, Spór i sądy, Warszawa: IPSiR Uniwersytetu Warszawskiego 1982, s. 52.

${ }^{48}$ Por. A. JAKUBIAK-MirońCZUK, Negocjacje dla prawników, s. 28. 
kowaniu konfliktu innej osobie ${ }^{49}$. Z uwagi, że niniejsze opracowanie osadzone jest w obszarze nauk prawnych, jego autor celowo posiłkując się dorobkiem doktryny, utożsamia pojęcie konfliktu ze sporem, stosując zamiennie przedmiotowe terminy.

Naturalną konsekwencją syntetycznego zaznaczenia, co należy rozumieć przez pojęcie konfliktu, jest przejście do sposobu jego rozwiązywania. W związku z tym poniżej zostanie zakreślona funkcja rozjemcza dialogu społecznego. Omówione zostaną pokrótce formy dialogu pomocne przy zażegnywaniu konfliktów oraz instytucje wyspecjalizowane do jego prowadzenia.

\section{ROLA DIALOGU SPOŁECZNEGO \\ W ROZWIĄZYWANIU KONFLIKTÓW SPOŁECZNYCH}

Obecna w państwach demokratycznych kultura dialogu ma w warunkach pluralistycznej demokracji pomóc osiągnąć konsensus obywatelski, który pozwoli zapewnić troskę o dobro wspólne ${ }^{50}$. Dialog społeczny jako wartość konstytucyjna, przedstawiona $\mathrm{w}$ preambule, legła u podstaw stosunków w państwie (zgodnie z wyrokiem TK z 1 maja 2005 r.) ${ }^{51}$, wskazując jednocześnie, w jaki sposób bądź przy udziale jakich czynników należy rozwiązywać zaistniałe spory. Za Trybunałem Konstytucyjnym należy przyjąć także, że dialog jako jeden z filarów społecznej gospodarki rynkowej powinien być urzeczywistniony na wszystkich szczeblach życia społecznego i gospodarczego (wyrok TK z 28 września 2006 r.) ${ }^{52}$.

Głównym celem instytucji dialogu społecznego są starania zmierzające do zachowania pokoju społecznego, co w sposób szczególny uwypukla rolę dialogu społecznego w rozwiązywaniu konfliktów ${ }^{53}$. „Pokój społeczny” to termin, którym posługuje się m.in. zbiorowe prawo pracy. W prawie tym mówi się wręcz o zasadzie zachowania pokoju społecznego, postrzeganej jako wartość nadrzędna, która pozwala układać relacje między pracą a kapitałem i zapewnia niezbędny ład w stosunkach pracy. Jak zostało wspomniane, idea pokoju społecznego realizowana jest na forum instytucji dialogu społecznego. Rolą tych instytucji od początku ich funkcjonowania było łagodzenie lub rozwiązywanie konfliktów w obszarach regulowanych przez

\footnotetext{
${ }^{49}$ Por. J. KurCZEwSKI, Spór i sądy, s. 51-52.

${ }^{50}$ Por. H. IzDEBSKI, Doktryny polityczno-prawne, s. 186-189.

${ }^{51}$ Sygn. akt K 18/04, OTK-A 2005, Nr 5, poz. 49.

52 Sygn. akt K 45/04, OTK-A 2006, Nr 8, poz. 111.

${ }^{53}$ Por. A. OgOnOwsKi, Ewolucja instytucji dialogu społecznego, s. 7.
} 
prawo pracy, w szczególności w czasie kryzysów społeczno-gospodarczych. Co równie istotne, przez zachowanie pokoju społecznego należy rozumieć nie tylko działania reaktywne, zmierzające do gaszenia istniejących już ognisk konfliktu, ale również (albo wręcz przede wszystkim) aktywność mającą na celu zapobieganie konfliktom, a więc także takie działania jak rozwój gospodarczy, konkurencyjność i inne.

Przechodząc do sposobów, w jakie może być prowadzony dialog społeczny, należy wskazać, że co do zasady przyjmuje on trzy podstawowe formy, tj. wymianę informacji, konsultacje oraz negocjacje (rokowanie). Na oficjalnej stronie internetowej poświęconej dialogowi społecznemu do form tych zalicza się także opiniowanie ${ }^{54}$. Nie można wykluczyć, że prowadzenie dialogu społecznego, przy wykorzystaniu tych form, może prowadzić nie tylko do zapobiegnięcia, ale i rozwiązania zaistniałych konfliktów społecznych.

Zasadniczym środkiem warunkującym poprawne prowadzenie dialogu jest wymiana informacji ${ }^{55}$. Informowanie może przyjmować dwie formy: bierną i aktywną. Pierwsza polega na tworzeniu dostępu do informacji publicznej, druga wiąże się z promocją informacji, np. poprzez ogłoszenia czy spotkania ${ }^{56}$. Na poziomie zakładowym prawo do informowania posiadaja działające związki zawodowe, rady pracowników oraz inne przedstawicielstwa pracownicze.

Kolejnym etapem dialogu są konsultacje oparte na współpracy partnerów społecznych, umożliwiające angaż w głębszy dialog dotyczący pojawiających się problemów ${ }^{57}$. Konsultacje polegają na przedstawieniu opinii partnerów społecznych podmiotowi zainteresowanemu, np. autorowi konsultowanego dokumentu na temat opiniowanej materii. Opinia wydana w ramach konsultacji nie jest wiążąca, podmiot konsultujący może, lecz nie musi uwzględnić uwag partnerów społecznych. $Z$ tego względu konsultacje, mimo że mogą być początkiem bądź zapowiedzią procesu negacyjnego, który miałby doprowadzić do podjęcia określonych decyzji, są uważane za mało skuteczną formę dialogu partnerów społecznych ${ }^{58}$.

Opiniowanie jest tą formą dialogu, którą można uznać za domenę przedstawicieli administracji państwowej, ponieważ to ona występuje z inicjatywą

\footnotetext{
${ }^{54}$ Por. K. KurZYŃSKA, Podstawowe pojęcia, hasło: Formy dialogu, http://www.dialog.gov.pl/ czym-jest-dialog-spoleczny/podstawowe-pojecia/ [dostęp: 20.02.2021].

${ }^{55}$ Por. R. TOWALSKI, Dialog społeczny, s. 18.

${ }^{56}$ Por. D. DŁugosz, J.J. Wygnański, Obywatele współdecydują. Przewodnik po partycypacji społecznej, Warszawa: Stowarzyszenie na rzecz Forum Inicjatyw Pozarządowych 2005, s. 24.

${ }^{57}$ Por. A. OgOnOwSKI, Ewolucja instytucji dialogu społecznego, s. 28.

${ }^{58}$ Tamże, s. 29.
} 
do związków zawodowych i organizacji pracodawców o opinię w sprawie polityki rządu ${ }^{59}$. Opinie te jednak nie są wiążące dla rządu. Przepisy prawa przewidują, w jakich sprawach rząd jest zobowiązany do zasięgnięcia opinii partnerów społecznych.

Zasadne jest, aby przy omawianiu kolejnej, a przy tym najbardziej intensywnej oraz skutecznej formie dialogu społecznego ${ }^{60}$, jaką są negocjacje, posiłkować się stanowiskiem Trybunału Konstytucyjnego. W wyroku z 30 stycznia 2001 r., sygn. akt K 17/00 (OTK 2001, Nr 1, poz. 4) przyjął on, że społeczna gospodarka rynkowa oparta na wartościach solidarności, dialogu i współpracy partnerów społecznych, o których mowa w art. 20 Konstytucji RP, „zakłada koncepcję równowagi interesów uczestników rynku i zarazem poszanowania ich autonomii, tworząc konstytucyjną gwarancję negocjacyjnego sposobu rozstrzygania spraw spornych, umożliwiającą przezwyciężanie napięć i konfliktów w procesie gospodarowania".

Uwzględniając powyższe, wskazać należy, że Trybunał Konstytucyjny kształtuje nakaz negocjacyjnego rozstrzygania spraw spornych, form wymiany informacji, prezentacji stanowisk czy instytucjonalnych gwarancji dyskursu społecznego (wyrok TK z 7 maja 2014 r.) ${ }^{61}$. W literaturze przedmiotu nakaz ten jest szeroko komentowany. Wskazuje się m.in., że celem dialogu społecznego jest osiągnięcie odpowiedniego kompromisu, którego wypracowanie jest możliwe zarówno dzięki opracowaniu odpowiednich ram prawnych, jak i uskutecznianiu mechanizmów umożliwiających prowadzenie negocjacji ${ }^{62}$.

Z uwagi na powyższe, forma ta jest najistotniejsza dla podkreślenia roli dialogu społecznego w rozwiązywaniu konfliktów. Uznaje się bowiem, że negocjacje mają doprowadzić do uzgodnienia stanowisk stron uczestniczących w procesie. Polegają one na współdecydowaniu, wiążą się ze wspólnym przygotowaniem i podjęciem jednomyślnej decyzji. Brak konsensusu wyklucza podjęcie decyzji w określonej sprawie ${ }^{63}$, ale nie wyklucza prowadzenia

\footnotetext{
${ }^{59}$ Por. K. KURZYŃSKA, Podstawowe pojęcia, hasło: Formy dialogu, http://www.dialog.gov.pl /czym-jest-dialog-spoleczny/podstawowe-pojecia/ [dostęp: 20.02.2021].

${ }^{60}$ Por. R. Towalski, Dialog społeczny, s. 19.

${ }^{61}$ Sygn. akt K 43/12, OTK-A 2014, Nr 5, poz. 50.

${ }^{62}$ Por. L. Garlicki, Komentarz do art. 20, [w:] Konstytucja Rzeczypospolitej Polskiej. Komentarz, red. L. Garlicki, t. III, Warszawa: Wydawnictwo Sejmowe 2003, s. 14; zob. M. WyrZYKOwSKI, Konstytucja negocjacji i kompromisu, [w:] Konstytucja, wybory, parlament. Studia ofiarowane Zdzisławowi Jaroszowi, red. L. Garlicki, Warszawa: Liber 2000, s. 230; zob. K. ZARADKIEwICZ, Komentarz do art. 20, [w:] Konstytucja RP. Komentarz. Art.1-86, red. M. Safjan, L. Bosek, t. I, Legalis, teza 158, 160-162.

${ }^{63}$ Por. D. DŁugosz, J.J. Wygnański, Obywatele współdecyduja, s. 25.
} 
dialogu. Ten bowiem nie musi oznaczać konieczności uzyskania jednomyślnej zgody partnerów społecznych (postanowienie TK z 2 września 2002 r.) ${ }^{64}$. „System negocjacyjny nie może skutkować niezdolnością do podjęcia jakiejkolwiek decyzji" (wyrok TK z 7 maja 2014 r.) ${ }^{65}$.

Jako przykład można wskazać negocjacje prowadzone w ramach opracowywania aktu prawnego. Stanowiska wypracowane przez partnerów społecznych podczas dialogu społecznego nad kształtem jakiegoś rozwiązania prawnego nie muszą zostać uwzględnione przez prawodawcę. Jak wskazano w orzecznictwie Trybunału Konstytucyjnego: „,...] choć art. 20 Konstytucji należy rozumieć jako nakaz zachowania dialogu, to nie wynika $z$ niego nakaz dochodzenia do treści ustaw tylko przez konsensus" (wyrok TK z 7 maja 2014 r., sygn. akt K 43/12, OTK-A 2014, Nr 5, poz. 50.). Warto w tym miejscu podkreślić, że art. 20 Konstytucji RP nie nakłada obowiązku konsultowania każdego aktu normatywnego (postanowienie TK z 2 września 2002 r.) ${ }^{66}$.

Kończąc rozważania na temat negocjacyjnej formy prowadzenia dialogu, należy zaznaczyć, że uczestnicy negocjacji, w tym wypadku partnerzy społeczni, są autonomiczni, a ich pozycja $\mathrm{w}$ procesie jest porównywalna. Konieczne jest więc zapewnienie wszystkim partnerom społecznym uczestniczącym w dialogu możliwie równorzędnej sytuacji negocjacyjnej (wyrok TK z 18 listopada 2002 r.) $)^{67}$.

Dialog społeczny może mieć charakter zinstytucjonalizowany lub pozainstytucjonalny, choć zdarza się, że stanowi ich kombinacje. Dialog pozainstytucjonalny może być realizowany poprzez zawieranie układów zbiorowych pracy oraz konsultacje i opiniowanie, prowadzone w ramach uprawnień partnerów społecznych. W tej formie dialogu dopuszcza się także organizowanie dialogu obywatelskiego z udziałem organizacji pozarządowych ${ }^{68}$. W literaturze przyjmuje się, że dialog pozainstytucjonalny jest podejmowany jako nieformalne działania ad $h o c^{69}$. Celem tak prowadzonego dialogu jest rozwiązywanie kluczowych w danym czasie problemów związanych $\mathrm{z}$ funkcjonowaniem państwa, które wymagają natychmiastowej reakcji ${ }^{70}$.

\footnotetext{
${ }^{64}$ Sygn. akt K 17/02, OTK-A 2002, Nr 5, poz. 68.

${ }^{65}$ Sygn. akt K 43/12, OTK-A 2014, Nr 5, poz. 50.

${ }^{66}$ Sygn. akt K 17/02, OTK-A 2002, Nr 5, poz. 68.

${ }^{67}$ Sygn. K 37/01, OTK ZU, Nr 6/A/2002, poz. 82.

${ }^{68}$ Por. K. KuRZYŃSKA, Podstawowe pojęcia, hasło: Formy dialogu, http://www.dialog.gov.pl/ czym-jest-dialog-spoleczny/podstawowe-pojecia/ [dostęp: 2.07.2021].

${ }^{69}$ Por. E. WronikowsKA, P. NowIK, Zbiorowe prawo pracy, Warszawa: Wydawnictwo C.H. Beck 2008, s. 26.

${ }^{70}$ Por. A. OGonowski, Ewolucja instytucji dialogu społecznego, s. 29.
} 
Z kolei dialog instytucjonalny jest mocno osadzony w ramach prawnych. Odbywa się on według zasad i w trybie ściśle określonym w przepisach prawa. Dialog rozumiany w tej formule prowadzony jest na forum instytucji dialogu społecznego. Rezultaty tak prowadzonego dialogu społecznego mogą przyjmować charakter formalnych postanowień, stanowiących ramy kształtowania polityki społeczno-gospodarczej ${ }^{71}$.

Instytucje dialogu społecznego, o których mowa, zostały określone w ustawie o dialogu społecznym, zgodnie z którą główne forum dialogu przedstawicieli pracowników, pracodawców i rządu stanowi Rada Dialogu Społecznego. Została ona powołana do prowadzenia dialogu w celu zapewnienia warunków rozwoju społeczno-gospodarczego oraz zwiększenia konkurencyjności polskiej gospodarki i spójności społecznej. Rada działa na rzecz realizacji zasady partycypacji i solidarności społecznej w zakresie zatrudnienia. W rozwikłaniu lub zapobieganiu konfliktom Rada dąży do poprawy jakości formułowania i wdrażania polityk oraz strategii społeczno-gospodarczych, a także do budowania wokół nich społecznego porozumienia. Działania te prowadzone są $\mathrm{w}$ drodze przejrzystego, merytorycznego i regularnego dialogu organizacji pracowników i pracodawców oraz strony rządowej.

Z punktu widzenia niniejszych rozważań kluczowa wydaje się kompetencja Rady polegająca na zawieraniu porozumień i zajmowania wspólnych stanowisk. Przedmiotem tych porozumień mogą być wzajemne zobowiązania stron służące realizacji celów Rady. Zawierają one m.in. informacje na temat czasu obowiązywania, trybu dokonywania zmian treści, trybu rozwiązania, przypadki wygaśnięcia oraz tryb rozstrzygania kwestii spornych. Porozumienia te nie mają charakteru normatywnego. W przeciwieństwie do porozumień określonych w ustawie o rozwiązywaniu sporów zbiorowych, stanowiących podstawy do zawierania układów zbiorowych pracy, nie można traktować ich jako swoistych źródeł prawa ${ }^{72}$.

Najistotniejszym dla zachowania pokoju społecznego uprawnieniem Rady wydaje się prawo do zajmowania stanowiska. Zgodnie z art. 4 ustawy o dialogu społecznym każdej ze stron Rady przysługuje prawo wniesienia pod obrady Rady spraw o dużym znaczeniu społecznym lub gospodarczym, których rozwiązanie jest ważne m.in. dla zachowania pokoju społecznego. Innymi

\footnotetext{
${ }^{71}$ Tamże.

72 J. MĘcINA, Komentarz do art. 3 w: Komentarz do ustawy o Radzie Dialogu Społecznego i innych instytucjach dialogu społecznego, [w:] Zbiorowe prawo pracy. Komentarz, 2016, LEX, teza 1.
} 
słowy: spraw, które mogą wywoływać strajki, protesty czy konflikty społeczne ${ }^{73}$. W literaturze przedmiotu przyjmuje się, że

Rada powinna monitorować, stabilizować i reagować na problemy istotne z punktu widzenia polityki społecznej i polityki gospodarczej oraz zachowania pokoju społecznego, a istota tego uprawnienia sprowadza się do możliwości inicjowania dialogu społecznego w zakresie spraw o dużym znaczeniu gospodarczym i społecznych w dowolnej konfiguracji, przez każdą ze stron, dwie strony oraz całą Radę.

Zajęcie stanowiska następuje w drodze uchwały. Może być ona podjęta zarówno w treści prezentującej jednolite i wspólne stanowisko stron, jak i wskazującej na różnice stanowisk poszczególnych stron lub organizacji.

Wymierne narzędzia w zakresie rozwiązywania konfliktów społecznych należą do kompetencji wojewódzkich rad dialogu społecznego (WRDS). Taka rada rozpatruje sprawy społeczne lub gospodarcze powodujące konflikty między pracodawcami i osobami wykonującymi pracę zarobkową, jeżeli uzna te sprawy za istotne dla zachowania pokoju społecznego. Sprawy te mogą być przedstawione WRDS na piśmie przez każdą ze stron uczestniczącą w konflikcie. Kompetencja ta, tzw. misja dobrej woli dotyczy spraw wykraczających co do zasady poza klasyczny spór zbiorowy, który toczy się według reguł ściśle określonych w ustawie o rozwiązywaniu sporów zbiorowych.

W sprawach - wniesionych pod obrady - zagrażających zachowaniu pokoju społecznego, WRDS może wyrazić opinię lub podjąć uchwałę o konieczności wyznaczenia osoby z misją dobrej woli. Zgodnie $\mathrm{z}$ ustawą o dialogu społecznym powinna to być osoba $\mathrm{z}$ listy mediatorów (o której mowa w art. 11 ustawy o sporach zbiorowych), w praktyce jednak może to być także inna osoba, ciesząca się autorytetem, co do której zgodę wyrażą strony konfliktu.

Rola osoby z misją dobrej woli polega na pomocy stronom konfliktu w jego rozwiązaniu. Osoba taka może korzystać ze wsparcia władz regionalnych, partnerów społecznych, urzędu ministra właściwego do spraw pracy oraz innych podmiotów i instytucji, którzy mogą przyczynić się do rozwiązania konfliktu. Osobie z misją dobrej woli na czas jej prowadzenia przysługuje zwolnienie od pracy, wynagrodzenie przewidziane w umowie zawartej z wojewodą (pokrywane z dotacji celowej), a także zwrot poniesionych przez nią kosztów przejazdu i zakwaterowania.

Brak możliwości rozwiązania sporu uprawnia strony konfliktu oraz osobę z misją dobrej woli do wystąpienia do WRDS o wyrażenie opinii. WRDS

73 J. MĘcINA, Komentarz do art. 4 w: Komentarz do ustawy o Radzie Dialogu Społecznego i innych instytucjach dialogu społecznego, [w:] tamże. 
wydając opinię może zawrzeć w niej ocenę prowadzonego sporu, a także apel do stron lub wniosek do organów lub instytucji w sprawie podjęcia działań lub decyzji, które pozwolą zażegnać konflikt. W sytuacji, w której rozwiązywany problem dotyczy decyzji administracji rządowej lub zmian w prawie znajdujących się w zakresie celów Rady Dialogu Społecznego, WRDS może zwrócić się do RDS o rozpatrzenie wniosku w trybie art. 11 ust. 1 ustawy o Radzie Dialogu Społecznego ${ }^{74}$.

Odnosząc się do praktyki, należy wskazać, że dialog regionalny na podstawie poprzedniej ustawy o Trójstronnej Komisji odgrywał ważną i pozytywną rolę w rozwiązywaniu konfliktów ${ }^{75}$. Potwierdzeniem postawionej tezy może być np. przeprowadzenie misji dobrej woli w SPZOZ w Puławach w 2012 r., które pozwoliło rozwiązać trwający półtora roku spór zbiorowy ${ }^{76}$, czy podpisanie porozumienia z dnia 7 czerwca 2013 r. jako zakończenie sporu w spółce PKN ORLEN S.A. w wyniku misji dobrej woli z udziałem mazowieckiej Wojewódzkiej Komisji Dialogu Społecznego ${ }^{77}$.

Obecnie, co należy zaznaczyć, w informatorach przygotowywanych przez ministra właściwego do spraw pracy w sprawie działalności WRDS w latach 2015-2020, a więc od momentu powołania WRDS, można zauważyć znaczący spadek udziału misji dobrej woli w rozwiązywaniu konfliktów. W 2019 r. przykładem takiego działania może być prowadzona misja dobrej woli pomiędzy rektorem Warszawskiego Uniwersytetu Medycznego a przedstawicielami związków zawodowych funkcjonujących w Szpitalu Klinicznym Dzieciątka Jezus w Warszawie ${ }^{78}$.

Przez tytułowe rozwiązywanie konfliktów autor niniejszych rozważań rozumie zarówno zażegnywanie sporu i rozwiązywanie sytuacji problemowych, jak i działalność czysto prewencyjną, tj. zmierzającą do uniknięcia

${ }^{74}$ Art. 11 ust. 1 ustawy o radzie dialogu społecznego: „Rada rozpatruje wnioski wojewódzkich rad dialogu społecznego, o których mowa w art. 41 ust. 1, o ile dotyczą one spraw objętych zakresem jej właściwości”.

${ }^{75}$ J. MĘcINA, Komentarz do art. 45 w: Komentarz do ustawy o Radzie Dialogu Spolecznego i innych instytucjach dialogu społecznego, [w:] Zbiorowe prawo pracy. Komentarz, LEX, 2016, teza 2.

${ }^{76}$ Ministerstwo Pracy i Polityki SpoŁecznej, Departament Dialogu i Partnerstwa Społecznego, Wojewódzkie Komisje Dialogu Społecznego działalność w 2013 r., Warszawa 2014, s. 55; http://www.dialog.gov.pl/gfx/mpips/userfiles/n.krasuska/n.krasuska/Informatory\%202013/Inform ator\%202013\%20-\%20WKDS.pdf [dostęp: 2.07.2021].

77 Tamże, s. 73.

${ }^{78}$ Informacja z działalności Wojewódzkich Rad Dialogu Społecznego w 2020 r., s. 8. http:// www.dialog.gov.pl/gfx/mpips/userfiles/n.krasuska/WRDS\%202020/Informacja $\% 20 \mathrm{z} \% 20 \mathrm{dzia} \% \mathrm{C}$ 5\%82alno\%C5\%9Bci\%20Wojew\%C3\%B3dzkich\%20Rad\%20Dialogu\%20Spo\%C5\%82ecznego \%20w\%202020\%20r.pdf [dostęp: 2.07.2021]. 
eskalacji napięcia. Taką też rolę dialogu społecznego należy upatrywać w rozwiązywaniu konfliktów społecznych. Prowadzony efektywnie przy udziale form lub instytucji, o których mowa powyżej, pozwala zapobiec manifestacjom i strajkom, zaspokajając interesy stron konfliktu. Warunkiem efektywnego dialogu jest chęć dialogowania, bowiem to najczęściej jej brak prowadzi do sytuacji konfliktowych.

\section{WNIOSKI}

Gwarancją odpowiedniego wykonywania zadań przez organy władzy publicznej jest dialog. Mowa o dialogu prowadzonym w różnych formach ze społeczeństwem, zarówno ogólnie, jak i z zainteresowanymi grupami lub jednostkami. Dialog społeczny jest instytucją konstytucyjną. Ustawodawca odwołujący się do dialogu społecznego w preambule do Konstytucji RP, ustanowił konstytucyjną zasadę dialogu społecznego. Wieloaspektowość tej zasady przejawia się nie tylko w obowiązku prowadzenia dialogu społecznego przez władze publiczne. Wynika $z$ niej także wymóg funkcjonowania „otwartego rządu”, polegający na zapewnieniu wszystkim podmiotom w państwie dostępu do informacji publicznej. Konsekwencją przyjęcia omawianej zasady jest również wymóg stworzenia warunków do swobodnego działania społeczeństwa obywatelskiego oraz konieczność stosowania zasady pomocniczości ${ }^{79}$. W art. 20 ustawy zasadniczej traktującym o ustroju gospodarki, dialog społeczny został wskazany jako jeden z podstawowych aspektów społecznej gospodarki rynkowej obok wartości takich, jak „solidarność i współpraca partnerów społecznych". Pomimo zapisów o obowiązku prowadzenia dialogu społecznego w Konstytucji RP i innych ustawach, ostatnimi czasy przeżywamy kryzys tej instytucji konstytucyjnej.

Kryzys dialogu społecznego obserwowany jest na wszystkich szczeblach - na poziomie krajowym, branżowym, a także na poziomie firm. Skuteczność dialogu zapewnia m.in. zachowanie pozbawione emocji, których w sytuacjach konfliktowych niestety nie brakuje, szczególnie w pogarszającej się sytuacji gospodarczej. Uznanie, że źródłem obecnych problemów jest wyłącznie pandemia COVID-19, może być niewystarczające. Borykamy się bowiem nie tylko $\mathrm{z}$ recesją dialogu społecznego, ale także kryzysem funkcjonowania zasady dialogu społecznego w ogólności. Nie można wykluczyć, że powodem zaistniałej sytuacji są próby podważania potrzeby obywatelskiego

\footnotetext{
${ }^{79}$ Por. H. IZDEBSKI, Doktryny polityczno-prawne, s. 193.
} 
konsensusu, który można osiągnąć przez dialog społeczny prowadzony w warunkach pluralistycznego i partycypacyjnego rozumienia demokracji.

Dialog staje się zużytą i wyczerpaną formułą, a zamiast rozmowy i współpracy wybierane jest samowładztwo. Ci, którzy powinni dzielić się władzą, co wynika z obowiązujących przepisów, zawłaszczają ją dla siebie, będąc przekonani o swojej nieomylności co do potrzeb innych. Liczy się szybkość, a nie jakość decyzji, która wymaga głębszego namysłu i konsultacji z innymi. Kolejny raz obserwujemy zjawisko bycia ponad prawem tych, którzy podobnie jak ich poprzednicy są przekonani, że działają w interesie społecznym ${ }^{80}$.

Opisywane działania są charakterystyczne dla demokracji postsocjalistycznych, w których postawa konfrontacji wciąż wydaje się silniejsza od kultury i potrzeby dialogu ${ }^{81}$.

Mając na względzie teoretyczne rozważania, które zostały przedstawione w niniejszym opracowaniu, podkreślić należy, że dialog społeczny pełni kluczową rolę w rozwiązywaniu konfliktów w państwie. Zasadne wydaje się wobec tego, aby w sytuacjach konfliktowych i problematycznych apelować o wykorzystywanie tych form rozstrzygania spraw spornych, które są charakterystyczne dla dialogu społecznego (np. negocjacje). Podsumowując, warto przypomnieć, że: „Dialog społeczny nie jest prawem władzy publicznej, lecz jej konstytucyjnym obowiązkiem, wykonywanym na rzecz rozwoju kraju oraz dążenia do osiągnięcia i utrzymywania pokoju społecznego" 82 .

\section{PIŚMIENNICTWO}

\section{Źródła prawa}

Ustawa z dnia 2 kwietnia 1997 r. - Konstytucja Rzeczypospolitej Polskiej, Dz.U. z 1997 r., $\mathrm{Nr} 78$, poz. 483 ze zm.

Ustawa z dnia 6 lipca 2001 r. o Trójstronnej Komisji do Spraw Społeczno-Gospodarczych i wojewódzkich komisjach dialogu społecznego, Dz.U. z 2001 r., Nr 100, poz. 1080 ze zm.

Ustawa z dnia 24 lipca 2015 r. o Radzie Dialogu Społecznego i innych instytucjach dialogu społecznego, tekst jedn.: Dz.U. z 2018 r., poz. 2232 ze zm.

Ustawy z dnia 23 maja 1993 r. o rozwiązywaniu sporów zbiorowych, tekst jedn.: Dz.U. z 2020 r., poz. 123 .

${ }^{80}$ M. GŁAdoch, O kryzysie dialogu społecznego, „Rzeczpospolita” 3.01.2019, https://www. rp.pl/Opinie/301039846-O-kryzysie-dialogu-spolecznego.html?cid [dostęp: 20.09.2020].

${ }^{81}$ Por. H. IZDEBSKI, Doktryny polityczno-prawne, s. 188.

${ }^{82}$ H. IZDEBSKI, Fundamenty wspótczesnych państw, s. 54. 
Ustawa z dnia 7 kwietnia 2006 r. o informowaniu pracowników i przeprowadzaniu z nimi konsultacji, Dz.U. z 2006 r., Nr 79, poz. 550.

Ustawa z dnia 20 kwietnia 2004 r. o promocji zatrudnienia i instytucjach rynku pracy, tekst jedn.: Dz.U. z 2020 r., poz. 1409.

\section{Literatura}

ANACIK Agata, KRUPNIK Seweryn, OtRĘBA Aleksandra [i in.]: Diagnoza stanu rozwoju sektorowego dialogu społecznego w skali ogólnopolskiej - badania ilościowe, Kraków: Wyższa Szkoła Europejska 2007.

Cisek-Lachowicz Marta, Kichewko Karolina: Dialog obywatelski w praktyce, „Studia z Polityki Publicznej" 5 (2018), nr 2 (18), s. 59-72.

DŁugosz Dagmir, Wygnański Jan: Obywatele współdecydują. Przewodnik po partycypacji spotecznej, Warszawa: Stowarzyszenie na rzecz Forum Inicjatyw Pozarządowych 2005.

FRIESKE Kazimierz, MACHOL-ZAJDA Lucyna: Instytucjonalne ramy dialogu spolecznego $w$ Polsce: szanse i ograniczenia, [w:] Dialog spoleczny w Polsce. Zasady, procedury $i$ instytucje wodniesieniu do podstawowych kwestii spolecznych, red. K. Frieske, L. Machol-Zajda, B. Urbaniak, Warszawa: Instytut Pracy i Spraw Socjalnych 1999.

GARDAwski Juliusz: Dialog społeczny w Polsce. Teoria, historia, praktyka, Warszawa: Ministerstwo Pracy i Polityki Społecznej/Katedra Socjologii Ekonomicznej SGH 2009.

GARLICKI Leszek: Komentarz do art. 20, [w:] Konstytucja Rzeczypospolitej Polskiej. Komentarz, red. L. Garlicki, t. III, Warszawa: Wydawnictwo Sejmowe 2003.

Garlicki Leszek: Wstęp, [w:] Konstytucja Rzeczypospolitej Polskiej. Komentarz, red. Leszek Garlicki, t. V, Warszawa: Wydawnictwo Sejmowe 2007.

Gąciarz Barbara, PAŃKów Włodzimierz: Dialog społeczny po polsku - fikcja czy szansa?, Warszawa: Instytut Spraw Publicznych 2001.

IZDEBSKI Hubert: Doktryny polityczno-prawne. Fundamenty współczesnych państw, Warszawa: Wolters Kluwer 2017.

IZDEBSKI Hubert: Fundamenty współczesnych państw, Warszawa: LexisNexis 2007.

JaKUbiaK-MirońCZuK Aneta: Negocjacje dla prawników. Prawo cywilne, Warszawa: Wolters Kluwer Polska 2010.

Jan PaweŁ II: Nauczanie społeczne, t. III, Warszawa: Ośrodek Dokumentacji i Studiów Społecznych 1984.

KozIELECKI Józef: Konflikty, teoria gier i psychologia, Warszawa: Państwowe Wydawnictwo Naukowe 1970.

KURCZEWSKI Jacek: Spór i sądy, Warszawa: IPSiR Uniwersytetu Warszawskiego 1982.

Majchrowski Jan, WinczoreK Piotr: Ustrój konstytucyjny Rzeczpospolitej Polskiej, Warszawa: Hortpress Sp. z o.o. 1998.

MęcInA Jacek: Komentarz do ustawy o Radzie Dialogu Spolecznego i innych instytucjach dialogu społecznego, [w:] Zbiorowe prawo pracy. Komentarz, 2016, LEX.

MiszTal Wojciech: Dialog, to znaczy co?, „Dialog. Pismo Dialogu Społecznego” 2017, nr 1 (52), s. 21-31. 
Ogonowski Andrzej: Ewolucja instytucji dialogu spolecznego w Polsce po 1989 roku. Studium ustrojowe, Warszawa: Wydawnictwo Sejmowe 2018.

Rossmanith Anna: Dialogiczna koncepcja prawa, Warszawa: Wolters Kluwer 2019.

STADNICZEŃKo Stanisław Leszek: Konstytucjonalizacja dialogu społecznego, „Studia Iuridica Lublinensia" 2014, t. 22, s. 317-332.

SUCHANEK Marek: Mediacja jako metoda rozwiazywania konfliktów spolecznych, „Studia Administracyjne" 2018, nr 10, s. 129-147.

TOWALSKI Rafał: Dialog społeczny - próba definicji, w: Dialog społeczny. Najnowsze dyskusje i koncepcje, red. R. Towalski, Warszawa: Centrum Partnerstwa Społecznego „Dialog” 2007.

WronikowsKA Ewa, Nowik Paweł: Zbiorowe prawo pracy, Warszawa: C.H. Beck 2008.

ZIELIŃSKI Tadeusz: Nowy ład pracy - rzeczywistość i wizja przyszłości, [w:] Nowy ład pracy w Polsce $i$ w Europie, red. M. Matey, Warszawa: Wydawnictwo Naukowe Scholar 1997.

WYRZYKOwsKi Mirosław: Konstytucja negocjacji i kompromisu, [w:] Konstytucja, wybory, parlament. Studia ofiarowane Zdzisławowi Jaroszowi, red. L. Garlicki, Warszawa: Liber 2000

Zaradkiewicz Kamil: Komentarz do art. 20, [w:] Konstytucja RP. Komentarz. Art.1-86, red. M. Safjan, L. Bosek, t. I, Legalis, teza 158, 160-162.

ŻuK Anna: Filozofia walki, Lublin: Wydawnictwo UMCS 1996.

\section{Netografia}

GŁADOCH Monika: O kryzysie dialogu spolecznego, „Rzeczypospolita” 3.01.2019, https:// www.rp.pl/Opinie/301039846-O-kryzysie-dialogu-spolecznego.html?cid [dostęp: 20.09.2020].

KURZYŃSKA Karolina: Podstawowe pojęcia. Dialog społeczny, czym jest, hasło: Dialog społeczny, formy dialogu, http://www.dialog.gov.pl/czym-jest-dialog-spoleczny/podstawowe-pojecia/ [dostęp: 20.01. oraz 20.02.2021].

Informacja z działalności Wojewódzkich Rad Dialogu Społecznego w 2020 r., s. 8, http://www. dialog.gov.pl/gfx/mpips/userfiles/n.krasuska/WRDS\%202020/Informacja\%20z\%20dzia\%C5\%8 2alno\%C5\%9Bci\%20Wojew\%C3\%B3dzkich\%20Rad\%20Dialogu\%20Spo\%C5\%82ecznego\%2 0w\%202020\%20r.pdf [dostęp: 2.07.2021].

Internetowa Encyklopedia PWN (hasła w serwisie encyklopedia.pwn.pl pochodzą z bazy encyklopedycznej Wydawnictwa Naukowego PWN, stanowiącej podstawę wydań wszystkich encyklopedii papierowych i multimedialnych), hasło: Dialog, https://encyklopedia.pwn.pl/ haslo/dialog;3892432.html [dostęp: 14.02.2021].

InTERnAtional Labour ORganization, ILO (2018). Social Dialogue, What is Social Dialogue?, http://www.ilo.org/ifpdial/areas-of-work/social-dialogue/lang--en/index.htm [dostęp: 1.07.2021].

Ministerstwo Pracy i Polityki Spolecznej, Departament Dialogu i Partnerstwa Społecznego, Wojewódzkie Komisje Dialogu Społecznego działalność w 2013 r., Warszawa 2014, s. 55.

http://www.dialog.gov.pl/gfx/mpips/userfiles/n.krasuska/n.krasuska/Informatory\%202013/Inform ator\%202013\%20-\%20WKDS.pdf [dostęp: 2.07 .2021 ]

DRABIK Lidia: Dialog, [w:] Stownik języka polskiego, red. J. Bralczyk, https://sjp.pwn.p1/sjp/; 2555065 [dostęp: 14.02.2021].

DRABIK Lidia: Konflikt, [w:] Stownik języka polskiego, red. J. Bralczyk, https://sjp.pwn.pl/sjp/ konflikt;2564275.html [dostęp: 14.02.2021]. 
DRABIK Lidia: Społeczeństwo, [w:] Slownik języka polskiego, red. J. Bralczyk, https://sjp.pwn.pl/ slowniki/spo\%C5\%82ecze\%C5\%84stwo.html [dostęp: 14 lutego 2021 r.].

DrABIK Lidia: Społeczny, [w:] Stownik języka polskiego, red. J. Bralczyk, https://sjp.pwn.pl/ sjp/spoleczny;2523113.html, [dostęp: 14.02.2021].

\section{ROLA DIALOGU SPOŁECZNEGO \\ W ROZWIĄZYWANIU KONFLIKTÓW SPOŁECZNYCH}

\section{Streszczenie}

Wpisana do preambuły Konstytucji RP zasada dialogu społecznego legła u podstaw stosunków w państwie. Analiza wpływu dialogu społecznego na relacje międzyludzkie skłania do refleksji na temat roli, jaką odgrywa on w rozwiązywaniu konfliktów społecznych. Artykuł przedstawia wyniki badań przeprowadzonych celem znalezienia odpowiedzi na pytanie o znaczenie dialogu społecznego w rozstrzyganiu sporów i rozładowywaniu napięć społecznych. W związku z tym zaprezentowane zostały formy, jakie przybiera dialog, próbując osiągnąć swój cel, jakim jest dążenie do zachowania pokoju społecznego.

Prezentując wyniki badań, należy zasygnalizować niepokojące zjawisko, jakim jest spłycanie roli instytucji dialogu społecznego. Marginalizacja dialogu społecznego, będącego jednym z gwarantów demokratycznego państwa prawnego, toruje drogę samowładztwu. Uznając kluczową rolę dialogu społecznego, jaką odgrywa w rozwiązywaniu konfliktów, zasadny wydaje się apel o jak najczęstsze uciekanie się do tych form rozstrzygania sporów, które są charakterystyczne dla dialogu społecznego. W artykule zachęca się do czynnego udziału w dialogu, a także przypomina o obowiązku do jego prowadzenia przez władze państwowe.

Słowa kluczowe: dialog społeczny; konflikt społeczny; Konstytucja RP; pokój społeczny; samowładztwo 